\title{
Relationship of Subjective Well-being of Citizens and Local Government Policy in Akita, Japan
}

\author{
Michiko Miyamoto*, Keisuke Watanabe
}

Akita Prefectural University, Japan

Copyright $\bigcirc 2017$ by authors, all rights reserved. Authors agree that this article remains permanently open access under the terms of the Creative Commons Attribution License 4.0 International License

\begin{abstract}
This paper presents a framework and an empirical analysis for "Citizens Awareness Survey" of 2,126 citizens over twenty-year old, conducted by the Akita local government to understand the feelings and needs of the citizens toward the prefectural policy. The results of the research model using Structural Equation Model (SEM) imply that Akita local government's policies in "Health and medical services," "Promotion of agriculture, forestry and fisheries," and "Employment and child care support" are related to their citizens' life satisfaction to some extent, while "Promotion of commerce and industry" and "Volunteer activities" are not.
\end{abstract}

Keywords Well-being, Life Satisfaction, Government Policy, Structural Equation Model

\section{Introduction}

Movements to measure progress by well-being indicators have become active worldwide, and Japan is no exception. Many local governments across Japan have been developing their own indicators of well-being and prosperity. In Akita Prefecture, its local government has been conducting the "Citizens Awareness Survey" since 2011, in order to understand the feelings and needs of the citizens toward the prefectural policy. The survey results have been used for the policy evaluation and the development of the management guidelines of the prefectural government's "the second phase hometown Akita well-being creation plan (tentative)"[7]. Akita is a large prefecture at the Sea of Japan coast in the northern Tohoku Region. Among Akita's main attractions are its natural beauty of mountains and the sea, and hot springs, and its economy remains dominated by traditional industries, such as agriculture, fishing, and forestry. This has led many young people to migrate to Tokyo and other large cities. It has the lowest number of children as a percentage of the population, at $11.2 \%$ [17]. Akita Prefecture is where declines in population are most severe in Japan. As of October 1, 2014, it has a population of just over 1 million people, where it had the highest rate of decrease of $1.26 \%$ according to the Japanese Statistics Bureau [18].

The authors test the association between Akita citizens' life satisfaction and factors related to the local government policy, such as "Promotion of commerce and industry," "Employment and child care assistance," "Health and medical services," "Promotion of agriculture, forestry and fisheries," and "Volunteer activities," using the dataset from "2014 Citizens Awareness Survey." This paper is structured as follows: in the next section the authors give a brief overview on well-being. Subsequently, a research model, hypotheses, data and variables are detailed. In the fifth section, the results are discussed as well as their implications.

\section{Related Works}

The theory of subjective well-being is "a person's evaluative reactions to his or her life - either in terms of life satisfaction (cognitive evaluation) or affect (ongoing emotional reactions)" [9]. Diener [8] proposed "Subjective Well-being" (SWB) which has three distinct components: life satisfaction (LS), positive affect (PA), and negative affect (NA). Later, Diener, Suh, Lucas, and Smith [10] included satisfaction in specific life domains (i.e., domain satisfaction [DS], e.g., satisfaction with health) in the definition of SWB.

There are some comparative studies of subjective well-being among different societies. Inglehart [11] found that all high-income countries rank high or medium-high on subjective well-being, which implies individuals in wealthier nations are far happier, on average, than people in less wealthy nations. Morrison, Tay, and Diener [16] examined the relationship between satisfaction with one's country and subjective well-being utilizing data from a representative worldwide poll, and found that national satisfaction was a strong positive predictor of 
individual-level life satisfaction.

The Gallup-Healthways Global Well-Being Index in 2013 conducted surveys in 135 countries to measures of well-being in five elements, such as purpose, social, financial, community, and physical [15]. The Index reported that residents of the Americas region are the most likely to be thriving in three or more elements $(33 \%)$, while those in sub-Saharan Africa are the least likely (9\%).

As for Japan, the movement toward measuring well-being started about 40 years ago, since the former Economic Planning Agency introduced a set of "Social Indicators," as alternative indexes to GDP [14]. "Social Indicators," which was revised to "New Social Indicators," focused more on individuals' lives, were used between 1974 and 1990. Then, indicators which measure well-being of Japanese people have developed as "People's Life Indicators" (1992-1999) and then as "Life Reform Index" (2002-2005). Most recently, "National Well-Being proposed well-being indicators-"was introduced in 2010. Japanese people are evaluated their well-being in terms of these factors; family, health, household budget (income and consumption), and mental relaxation (or free time), according to a survey conducted in 2009 and 2010 [6]. The figure 1 presents a framework of well-being indicators in Japan, which suggested by the commission on measuring well-being of Japanese Cabinet Office.

\section{Well-being}

\section{Subjective Well-being}

\begin{tabular}{|c|c|c|}
\hline $\begin{array}{l}\text { Socio-economic } \\
\text { condision }\end{array}$ & Health & Relatedness \\
\hline $\begin{array}{l}\text { - Basic Needs } \\
\text { - Housing } \\
\text { - Parenting/Education } \\
\text { - Employment } \\
\text { - Social System }\end{array}$ & $\begin{array}{l}\text { - Physical Health } \\
\text { - Psychological } \\
\text { Health }\end{array}$ & $\begin{array}{l}\text { - Lifestyle } \\
\text { - Familyties } \\
\text { - Bonding with } \\
\text { Community } \\
\text { - Closeness to Nature }\end{array}$ \\
\hline \multicolumn{3}{|c|}{ Sustainablity } \\
\hline
\end{tabular}

(Source: Cabinet Office 2011 [6])

Figure 1. A framework for measuring well-being

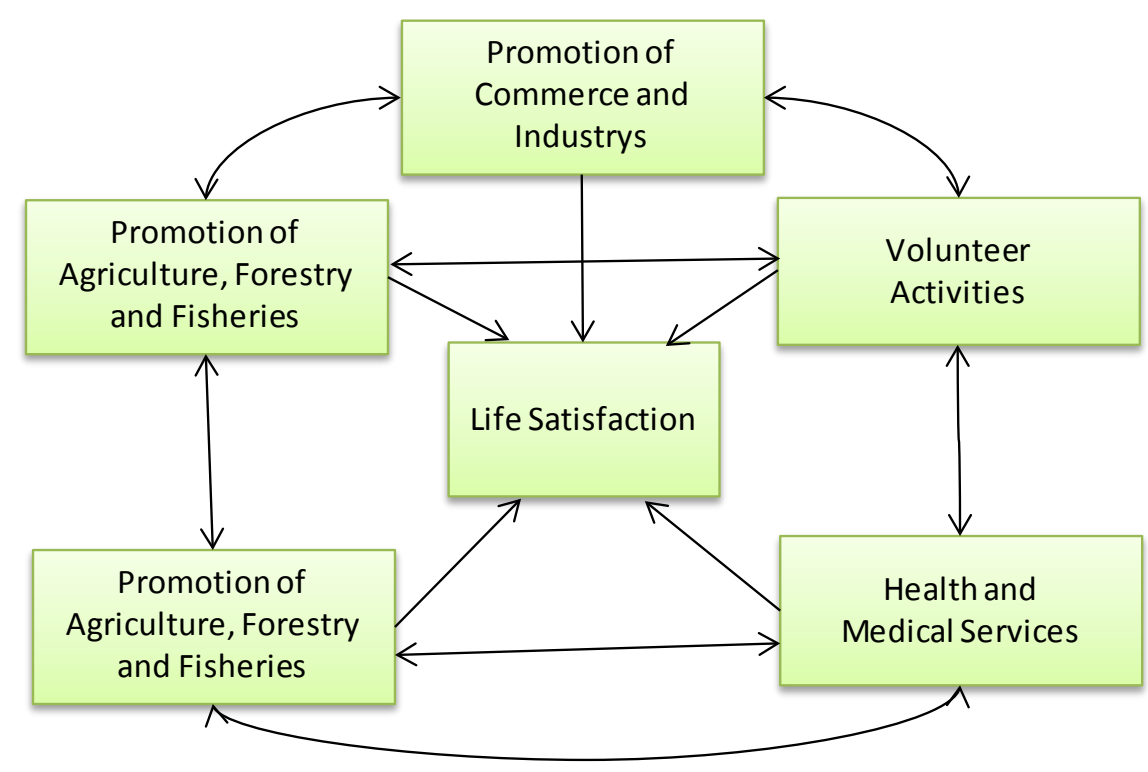

Figure 2. A Research Model 


\section{Research Model and Hypotheses}

Based on the framework of measuring well-being suggested by previous literature and Japanese Cabinet Office as conceptual frameworks, the author would like to propose the research model to gain a better understanding of relationships among Akita citizens' life satisfaction and the local government policy related factors, such as "Promotion of commerce and industry," "Employment and child care assistance," "Health and medical services," "Promotion of agriculture, forestry and fisheries," and "Volunteer activities." According to the purpose of this study, the research framework was developed as shown in Fig. 2.

The author had formed five hypotheses based on this framework as follows.

H1: There is a significant, positive relationship between factors related to Promotion of commerce and industry and Life Satisfaction.

H2: There is a significant, positive relationship between factors related to Employment and child care assistance and Life Satisfaction.
H3: There is a significant, positive relationship between factors related to Health and medical services and Life Satisfaction.

H4: There is a significant, positive relationship between factors related to Promotion of agriculture, forestry and fisheries and Life Satisfaction.

H5: There is a significant, positive relationship between factors related to volunteer activities and Life Satisfaction.

\section{Data}

Based on the prefectural policy called "A Hometown Akita Well-Being Creation Plan" started in 2010, Akita prefectural government has tried to measure status quo of each strategy in the plan by conducting a questionnaire survey to the citizens of Akita every year. The questionnaire used for this study was sent by mail from June 25, 2014 to July 14, 2014. Questionnaires were mailed to 4,000 male and female over twenty-year old that live in Akita. A two-stage random sampling method stratified on the basis of the Basic Resident Register was used.

Table 1. Description of the samples

\begin{tabular}{|c|c|c|c|c|c|}
\hline & \multirow{2}{*}{ Attributes } & \multicolumn{2}{|c|}{ Valid Responses } & \multicolumn{2}{|c|}{$\begin{array}{l}\text { Estimated Population } \\
\text { (as of Oct. 1, 2013) }\end{array}$} \\
\hline & & Number & $(\%)$ & $\begin{array}{l}\text { Over 18-year- } \\
\text { old }\end{array}$ & $(\%)$ \\
\hline & Total & 2,126 & 100.0 & 886,114 & 100 \\
\hline \multirow{3}{*}{ Sex } & Male & 979 & 46.0 & 408,386 & 46.1 \\
\hline & Femail & 1,103 & 51.9 & 477,728 & 53.9 \\
\hline & No answer & 44 & 2.1 & - & - \\
\hline \multirow{7}{*}{ Age } & $20-29$ & 146 & 6.9 & 77,063 & 8.4 \\
\hline & $30-39$ & 279 & 13.1 & 113,839 & 12.8 \\
\hline & $40-49$ & 12 & 14.7 & 123,077 & 13.9 \\
\hline & $50-59$ & 437 & 20.6 & 148,997 & 16.8 \\
\hline & $60-69$ & 503 & 23.7 & 170,688 & 19.3 \\
\hline & 70 years old- & 404 & 19.0 & 255,450 & 28.8 \\
\hline & No answer & 45 & 2.1 & - & - \\
\hline \multirow{6}{*}{ Family Structure } & Single & 167 & 709.0 & & \\
\hline & Husband and wife only & 427 & 20.1 & & \\
\hline & Parent-child two generations & 889 & 41.8 & & \\
\hline & Parent-child-grandchild three generations & 434 & 20.4 & & \\
\hline & Others & 117 & 5.5 & & \\
\hline & No answer & 92 & 4.3 & & \\
\hline \multirow{6}{*}{ Length of Residence } & Less than 5 years & 34 & 1.6 & & \\
\hline & 5-9 (years) & 25 & 1.2 & & \\
\hline & $10-19$ & 86 & 4.0 & & \\
\hline & $20-29$ & 208 & 9.8 & & \\
\hline & Over 30 years & 1,687 & 79.4 & & \\
\hline & No answer & 86 & 4.0 & & \\
\hline
\end{tabular}


Table 2. A list of variables

\begin{tabular}{|c|c|c|}
\hline $\begin{array}{l}\text { Promotion of commerce } \\
\text { and industry }\end{array}$ & $\begin{array}{l}\text { Q1 } \\
\text { Q2 } \\
\text { Q4 } \\
\text { Q4 } \\
\text { Q8 } \\
\text { Q7 } \\
\text { Q3 } \\
\text { Q9 } \\
\text { Q6 } \\
\text { Q17 }\end{array}$ & $\begin{array}{l}\text { Efforts of the development of new industrial products and new technologies by local companies } \\
\text { Efforts of technology entrants by local companies to major companies } \\
\text { Overall, activities on the promotion of tourism, industry and commerce and trade } \\
\text { Efforts of the creation of new energy promotion and related industries } \\
\text { Efforts on development assistance and selling of processed goods } \\
\text { Situation of company location and attract activities in the prefecture } \\
\text { Attract activities of tourism and business visitors from other part of Jap an and abroad } \\
\text { Promotion of environmental recycling business by taking advantage of mine -related technology } \\
\text { Efforts for human resource development to support the prefecture industry } \\
\text { Efforts of trade and economic exchanges with foreign countries such as China and Russia } \\
\text { Efforts of research in the development of new varieties and new technology }\end{array}$ \\
\hline $\begin{array}{l}\text { Employment and child } \\
\text { care assistance }\end{array}$ & $\begin{array}{l}\text { Q30 } \\
\text { Q28 } \\
\text { Q27 } \\
\text { Q26 } \\
\text { Q29 } \\
\text { Q23 } \\
\text { Q22 } \\
\text { Q24 } \\
\text { Q25 } \\
\text { Q33 } \\
\text { Q54 }\end{array}$ & $\begin{array}{l}\text { Feeling toward the declining birthrate } \\
\text { Economic support for child caring families } \\
\text { Maintaining friendly environment for childbirth and child-rearing } \\
\text { Support for childcare and home compatible with the work by the company } \\
\text { Support system to child caring home by Region } \\
\text { System to support efforts for the declining birthrate } \\
\text { Enlightenment movement about the declining birthrate } \\
\text { Promotional effort for young people within the prefecture employment and "coming back to Akita"campaign } \\
\text { Support to single men and women of dating and marriage } \\
\text { Efforts for suicide prevention } \\
\text { A child birth and raised-friendly environment in your family, community, and in the workplace. }\end{array}$ \\
\hline $\begin{array}{l}\text { Health and medical } \\
\text { services }\end{array}$ & \begin{tabular}{l|} 
Q38 \\
Q36 \\
Q37 \\
Q35 \\
Q34 \\
Q32 \\
Q31
\end{tabular} & $\begin{array}{l}\text { Health and medical services } \\
\text { Development status of the General Hospital of the region } \\
\text { Ease of use of hospital } \\
\text { Medical systems for emergency medical care, pregnancy and childbirth } \\
\text { Efforts for physicians ensure by province } \\
\text { Comprehensive measures due to cancer screening and cancer health care provider system maintenance, etc. } \\
\text { Efforts to improve, such as eating habits for the lifestyle-related disease prevention }\end{array}$ \\
\hline $\begin{array}{l}\text { Promotion of agriculture, } \\
\text { forestry and fisheries }\end{array}$ & $\begin{array}{l}\text { Q21 } \\
\text { Q16 } \\
\text { Q12 } \\
\text { Q15 } \\
\text { Q10 } \\
\text { Q19 } \\
\text { Q14 } \\
\text { Q11 } \\
\text { Q18 } \\
\text { Q13 }\end{array}$ & $\begin{array}{l}\text { Promotion of agriculture, forestry and fisheries } \\
\text { Secure and develop the leaders of agriculture and fisheries } \\
\text { Locality development of agricultural and livestock products } \\
\text { Cooperative efforts of agriculture, commerce and industry for food development } \\
\text { Efforts of forest management and forest road maintenance such as thinning } \\
\text { Efforts of infrastructure development such as paddy fields and agricultural irrigation canals } \\
\text { PR activities of the prefecture production of agriculture, forestry and fishery products } \\
\text { Direct sales and processing of agricultural product. Efforts of the new business development. } \\
\text { Efforts of dissemination and establishment of new breed and new technology } \\
\text { Production and provision system of safe and secure county agricultural products }\end{array}$ \\
\hline Volunteer activities & $\begin{array}{l}\text { Q43 } \\
\text { Q39 } \\
\text { Q40 } \\
\text { Q42 } \\
\text { Q41 }\end{array}$ & $\begin{array}{l}\text { The local community building (people collaborate with each other) } \\
\text { The residents particip ate in volunteer activities and NPOs, etc. } \\
\text { Support to the NPO and volunteer activities, etc. } \\
\text { Services to local residents by a coopretation of prefecture and municip ality } \\
\text { Deployment of new business by local residents }\end{array}$ \\
\hline
\end{tabular}


There were 2,132 responses with a response rate of 53.3\%. After omitting ineligible responses, 2,126 (53.2\%) were used for the analyses. Most of the questionnaires are asked using a 10 point scale. A list of description of the samples is shown in Table 1, a list of variables is shown in Table 2, and response rates by different cities in Akita are shown in Fig. 3. Certain respondent characteristics were compared with the 2013 census data of Akita in Table 1. Age comparisons indicate that the survey sample and the 2013 census data have different distributions in each age group. The sample has more people between 50 to 69 years old, and less in 70 years old and older. The census includes very old people, as shown in fig. 4, who may have difficulties with responding to those questionnaires. This suggests that the baby boomers may be overrepresented and the septuagenarian and older residents under-presented in the sample. No comparison was made on family structure because the 2013 census data was not available. Citizens, who live around Akita city, a capital city of Akita prefecture, responded the survey the most.

A question, which asks for the life satisfaction, is "Overall, how satisfied are you with your daily life?" Zero means he/she is "completely dissatisfied" and ten means he/she is "completely satisfied." A histogram of the life satisfaction in Akita is shown in Fig. 5. Most people answered between three to eight points, and five is the highest.

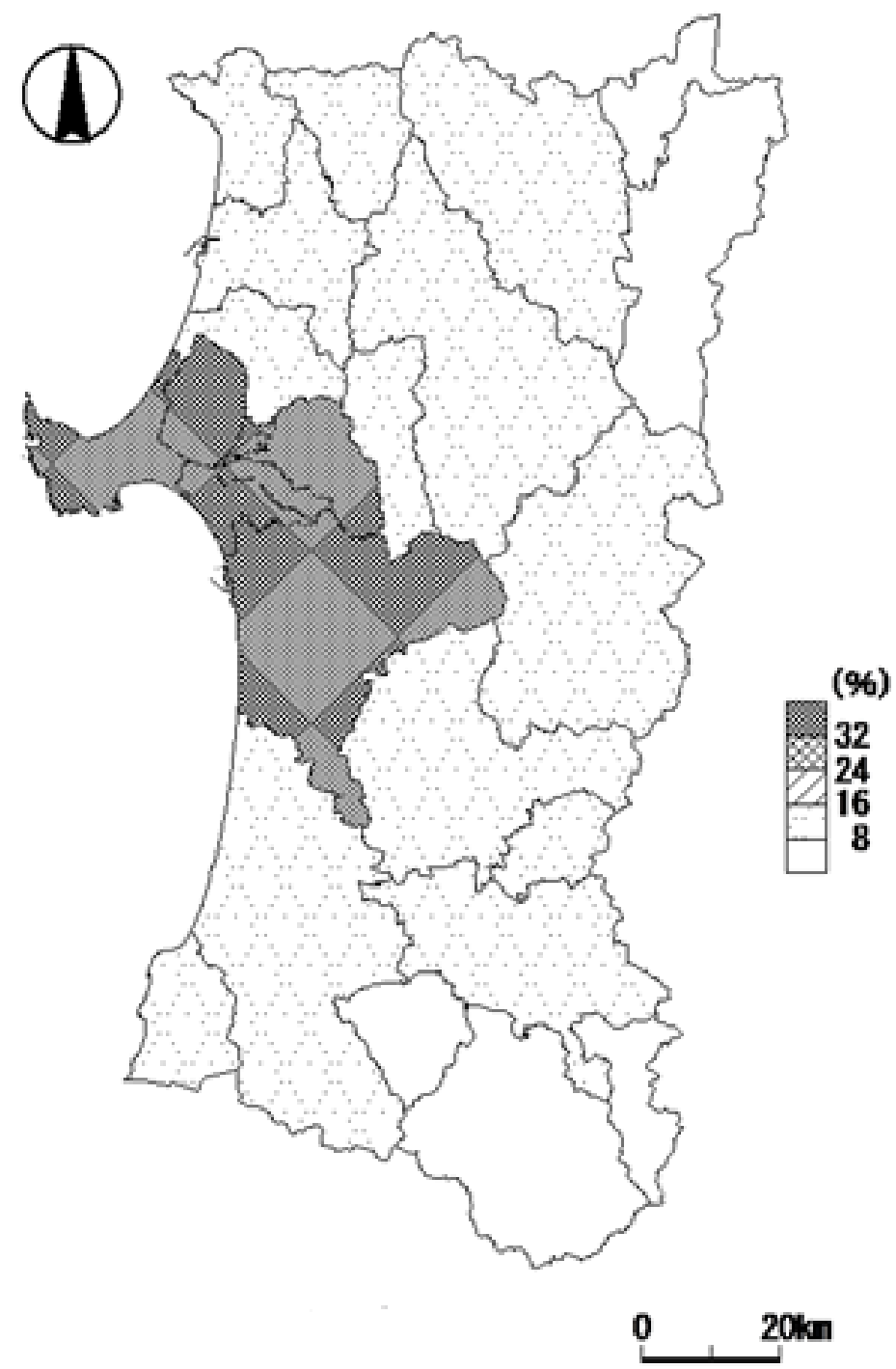

Figure 3. Response Rates by Cities 


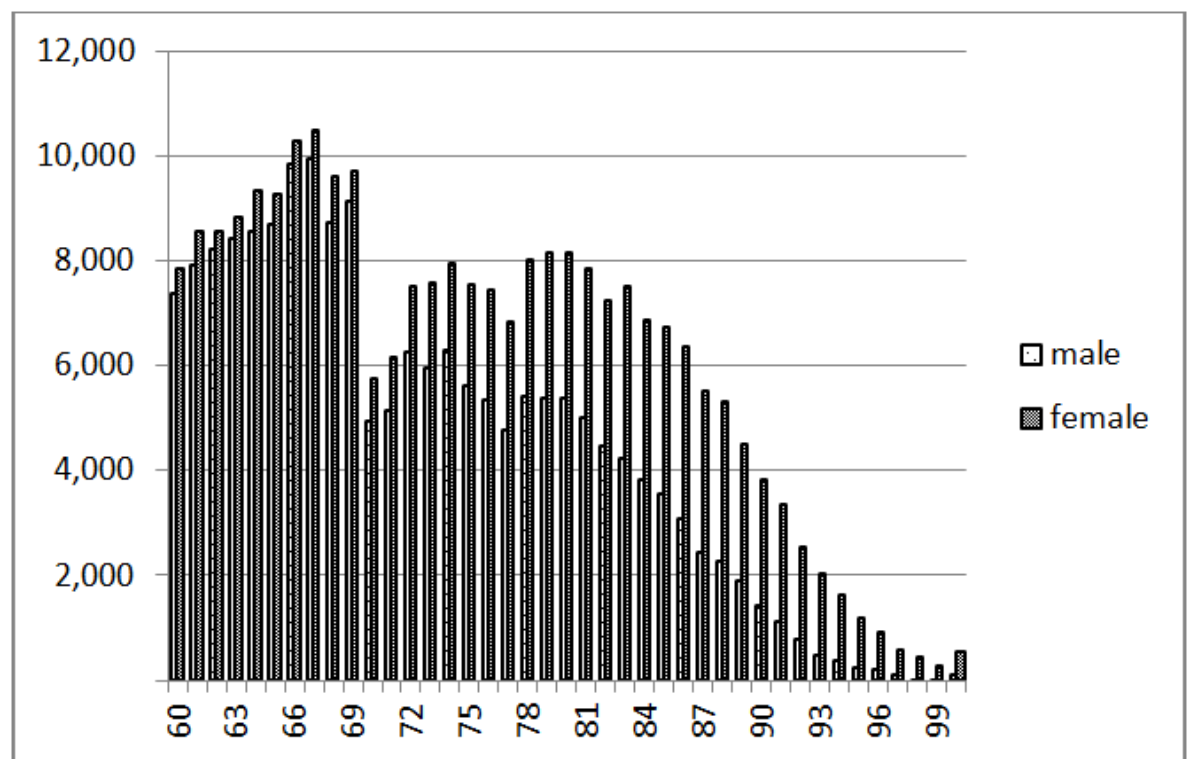

Figure 4. People older than 60-year old in Akita based on the 2015 Census Data.

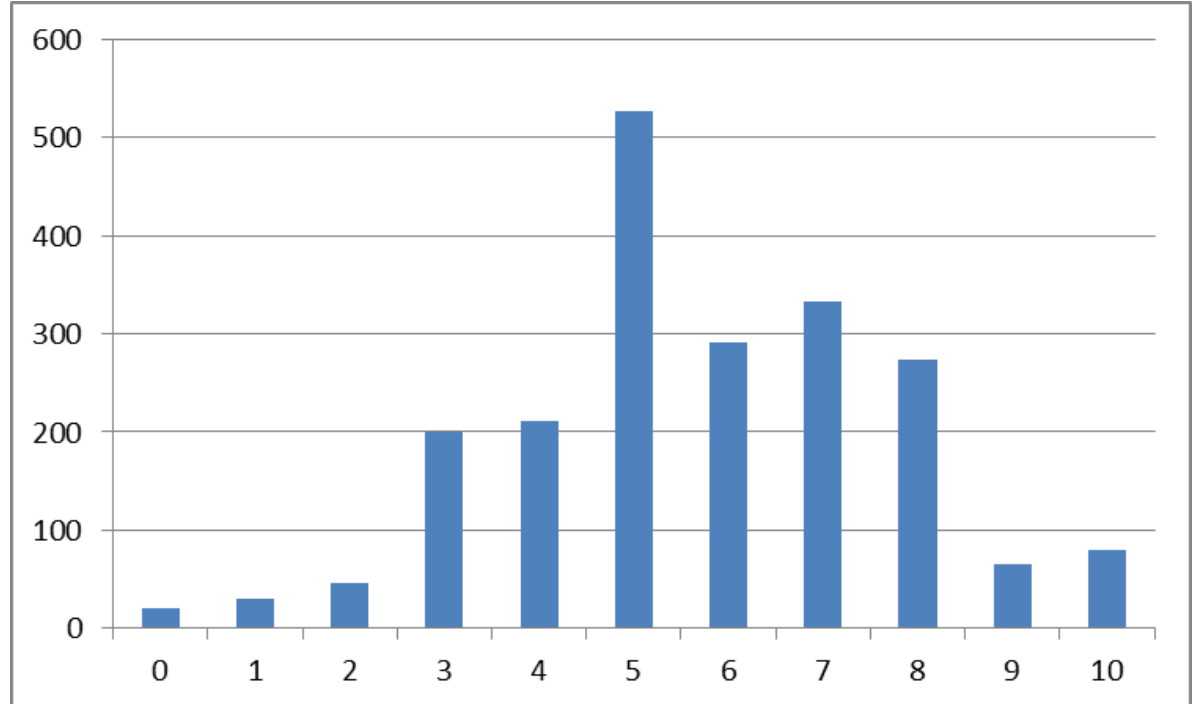

Figure 5. The Life Satisfaction in Akita

\section{Results}

Testing the efficacy of the structural equation model was conducted by AMOS 22, and the major results of analysis for the entire respondents are shown in Fig. 6 and the results for the entire respondents and each age group are shown in Table 3. The path diagram highlights the structural relationships. In this diagram, the measured variables are enclosed in boxes, latent variables are circled, and arrows connecting two variables represent relations, and open arrows represent errors.

When SEM is used to verify a theoretical model, a better goodness of fit is required for SEM analysis [5]; the better the fit, the closer the model matrix and the sample matrix. By means of various goodness-of-fit indexes, including the comparative fit index (CFI) [2], the incremental fit index (IFI)
[3], and the root mean squared error of approximation (RMSEA)[3], the estimated matrix can be evaluated against the observed sample covariance matrix to determine whether the hypothesized model is an acceptable representation of the data. In general, incremental fit indexes (i.e., CFI, IFI) above 0.90 signify good model fit. RMSEA values lower than 0.08 signify acceptable model fit, with values lower than 0.05 indicative of good model fit [4]. The research model is shown in figure 4; CFI $=0.906, \mathrm{IFI}=0.906, \mathrm{RMSEA}=0.05$ (see Table 4). The Path Coefficient for the structural model suggested that the regression coefficient for all constructs, except promotion of commerce and industry to life satisfaction, and volunteer activities to life satisfaction, show significance. Since all of the indexes satisfy the cut-off values, these results are regarded as acceptable.

The followings are results of hypotheses. 
H1: There is a positive but not significant relationship between factors related to Promotion of commerce and industry and Life Satisfaction.

$\mathrm{H} 2$ : There is a significant, positive relationship between factors related to Employment and child care assistance and Life Satisfaction.

H3: There is a significant, positive relationship between factors related to Health and medical services and Life Satisfaction.

H4: There is a significant, positive relationship between factors related to Promotion of agriculture, forestry and fisheries and Life Satisfaction.

H5: There is a negative and not significant relationship between factors related to Volunteer activities and Life Satisfaction.

However, some age groups show differences in their responses for promotion of agriculture, forestry and fisheries, and employment and child care assistance. A relationship between factors related to Promotion of agriculture, forestry and fisheries and Life Satisfaction is positive and significant at $10 \%$ for an entire respondents and a group of 20-39 years old, but not significant for 40-59 years and 60 plus age groups. According to Ministry of Agriculture, Forestry and Fisheries (MAFF) of Japan, the balance among the age composition of the core agricultural workers has collapsed, with $61 \%$ (770,000 people) over 65 years old and $10 \%$ (180,000 people) under 40 years old. [12]. Although a number of new farmers in 2012 decreased for the age group of 40 years old to 59 years old and over 60 years old, those of age group of under 39 years old increased by $6 \%$ compared with the previous year to 15,030 persons. Unfortunately, about $30 \%$ of new farmers aged 39 or younger have left farming within a few years, because of lack of prospects for living [13]. Our results seem to reflect those facts behind agriculture. As for a relationship between Employment and child care assistance and Life Satisfaction, all age groups except 60 plus are positive and significant; a 60 plus age group is negative and statistically not significant. It seems that older generation has already retired from employment and child care, and has lost their interest in them.

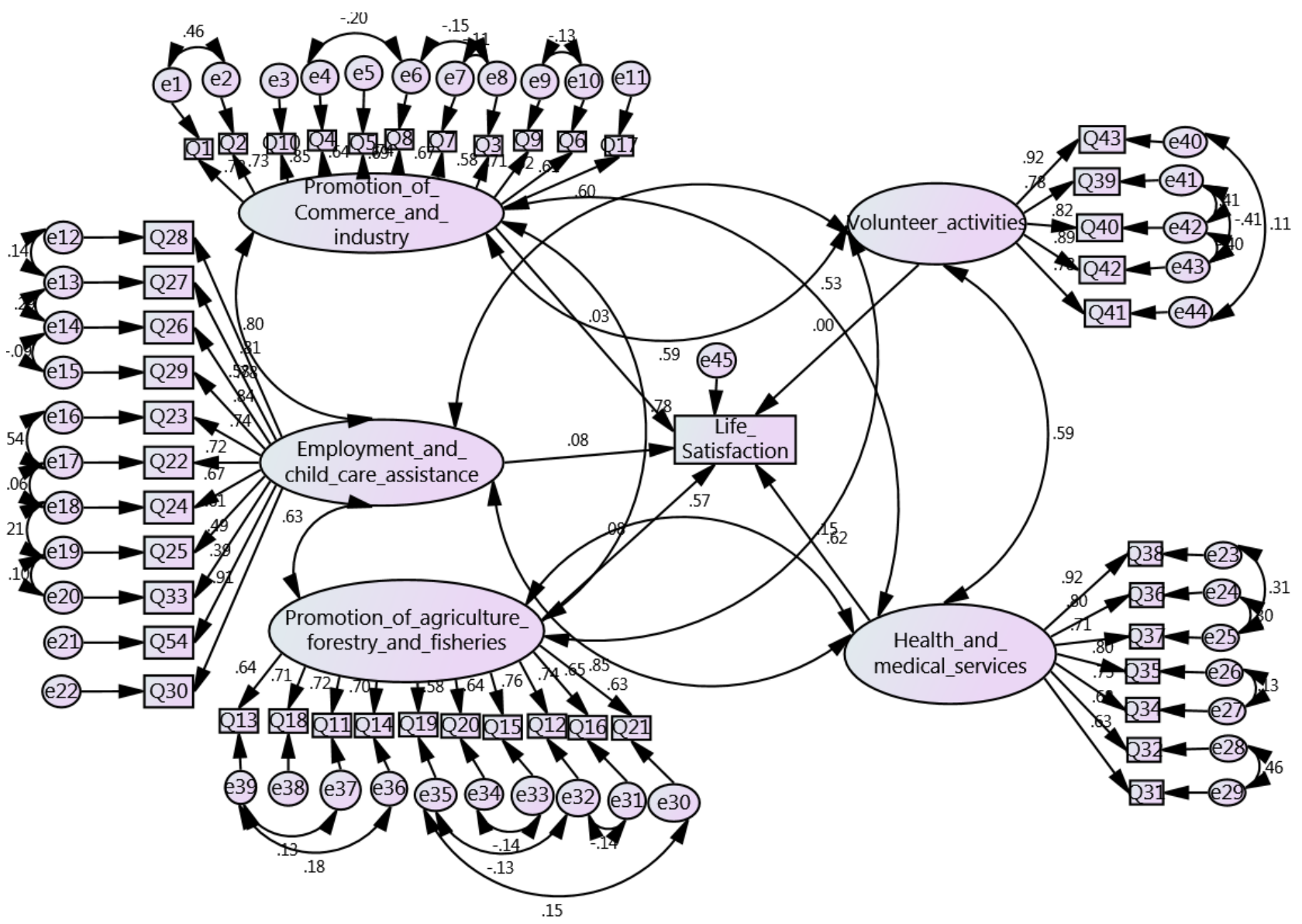

Figure 6. Results of the Research Model (All Respondents) 
Table 3. The Path Coefficients of the Research Model

\begin{tabular}{|c|c|c|c|c|c|c|}
\hline \multicolumn{3}{|c|}{ construct } & \multirow{2}{*}{$\begin{array}{c}\text { All } \\
0.719\end{array}$} & \multirow{2}{*}{$\begin{array}{c}\begin{array}{c}20-39-y e a r \\
\text { old }\end{array} \\
0.715\end{array}$} & \multirow{2}{*}{$\begin{array}{c}\begin{array}{c}40-59-y e a r \\
\text { old }\end{array} \\
0.713\end{array}$} & \multirow{2}{*}{$\begin{array}{c}60 \text { plus } \\
0.739\end{array}$} \\
\hline Q1 & Efforts of the development of new industrial products and new technologies by local companies & $<--$ Promotion of commerce and industry & & & & \\
\hline Q2 & Efforts of technology entrants by local companies to major companies & $<--$ Promotion of commerce and industry & $0.732^{* * *}$ & $0.72^{* * *}$ & $0.729^{* * *}$ & $0.751^{* * *}$ \\
\hline Q4 & Efforts of the creation of new energy promotion and related industries & $<---$ Promotion of commerce and industry & $0.642^{* * *}$ & $0.626^{* * *}$ & $0.673^{* * *}$ & $0.628^{* * *}$ \\
\hline Q5 & Efforts on development assistance and selling of processed goods & $<--$ Promotion of commerce and industry & $0.692^{* * *}$ & $0.652^{* * *}$ & $0.718^{* * *}$ & $0.697 * * *$ \\
\hline Q8 & Situation of company location and attract activities in the prefecture & $<--$ Promotion of commerce and industry & $0.737^{* * *}$ & $0.763^{* * *}$ & $0.705^{* * *}$ & $0.738^{* * *}$ \\
\hline Q7 & Attract activities of tourism and business visitors from other part of Japan and abroad & $<--$ Promotion of commerce and industry & $0.67 * * *$ & $0.659^{* * *}$ & $0.696^{* * *}$ & $0.618^{* * *}$ \\
\hline Q3 & Promotion of environmental recy cling business by taking advantage of mine -related technology & $<---$ Promotion of commerce and industry & $0.581^{* * *}$ & $0.612 * * *$ & $0.554^{* * *}$ & $0.615^{* * *}$ \\
\hline Q9 & Efforts for human resource development to support the prefecture industry & $<---$ Promotion of commerce and industry & $0.711^{* * *}$ & $0.696^{* * *}$ & $0.722^{* * *}$ & $0.697^{* * *}$ \\
\hline Q6 & Efforts of trade and economic exchanges with foreign countries such as China and Russia & $<--$ Promotion of commerce and industry & $0.616^{* * *}$ & $0.622 * * *$ & $0.634^{* * *}$ & $0.55^{* * *}$ \\
\hline Q17 & Efforts of research in the development of new varieties and new technology & $<---$ Promotion of commerce and industry & $0.608^{* * *}$ & $0.575^{* * *}$ & $0.603^{* * *}$ & $0.681^{* * *}$ \\
\hline Q28 & Economic support for child caring families & $<---$ Emp loyment and child care assistance & 0.803 & 0.799 & 0.802 & 0.828 \\
\hline Q27 & Maintaining friendly environment for childbirth and child-rearing & $<---$ Employment and child care assistance & $0.812^{* * *}$ & $0.792 * * *$ & $0.823^{* * *}$ & $0.836^{* * *}$ \\
\hline Q26 & Support for childcare and home compatible with the work by the company & $<---$ Employment and child care assistance & $0.785^{* * *}$ & $0.765^{* * *}$ & $0.793^{* * *}$ & $0.797^{* * *}$ \\
\hline Q29 & Support system to child caring home by Region & $<---$ Employment and child care assistance & $0.843^{* * *}$ & $0.859^{* * *}$ & $0.833^{* * *}$ & $0.838^{* * *}$ \\
\hline Q23 & System to support efforts for the declining birthrate & $<---$ Employment and child care assistance & $0.742^{* * *}$ & $0.733^{* * *}$ & $0.751^{* * *}$ & $0.74^{* * *}$ \\
\hline Q24 & $\begin{array}{l}\text { Promotional effort for young people within the prefecture employment and "coming back to } \\
\text { Akita"campaign }\end{array}$ & $<---$ Employment and child care assistance & $0.669^{* * *}$ & $0.64^{* * *}$ & $0.685^{* * *}$ & $0.69^{* * *}$ \\
\hline Q25 & Support to single men and women of dating and marriage & $<---$ Employment and child care assistance & $0.61^{* * *}$ & $0.56^{* * *}$ & $0.638^{* * *}$ & $0.68^{* * *}$ \\
\hline Q33 & Efforts for suicide prevention & $<---$ Employment and child care assistance & $0.486^{* * *}$ & $0.451^{* * *}$ & $0.518^{* * *}$ & $0.47^{* * *}$ \\
\hline Q54 & A child birth and raised-friendly environment in your family, community, and in the workplace. & $<---$ Emp loyment and child care assistance & $0.386^{* * *}$ & $0.444^{* * *}$ & $0.35^{* * *}$ & $0.335^{* * *}$ \\
\hline Q30 & Feeling toward the declining birthrate & $<---$ Employment and child care assistance & $0.912^{* * *}$ & $0.919^{* * *}$ & $0.915^{* * *}$ & $0.906^{* * *}$ \\
\hline Q38 & Health and medical services & $<---$ Health and medical services & 0.919 & 0.926 & 0.93 & 0.868 \\
\hline Q36 & Development status of the General Hospital of the region & $<---$ Health and medical services & $0.797^{* * *}$ & $0.786^{* * *}$ & $0.806^{* * *}$ & $0.807^{* * *}$ \\
\hline Q37 & Ease of use of hospital & $<---$ Health and medical services & $0.715^{* * *}$ & $0.691^{* * *}$ & $0.746^{* * *}$ & $0.684 * * *$ \\
\hline Q35 & Medical systems for emergency medical care, pregnancy and childbirth & $<---$ Health and medical services & $0.798^{* * *}$ & $0.769^{* * *}$ & $0.798^{* * *}$ & $0.821^{* * *}$ \\
\hline Q34 & Efforts for physicians ensure by province & $<---$ Health and medical services & $0.749^{* * *}$ & $0.737^{* * *}$ & $0.74 * * *$ & $0.762 * * *$ \\
\hline Q32 & $\begin{array}{l}\text { Comprehensive measures due to cancer screening and cancer health care provider system } \\
\text { maintenance, etc. }\end{array}$ & $<---$ Health and medical services & $0.678^{* * *}$ & $0.656^{* * *}$ & $0.689^{* * *}$ & $0.671^{* * *}$ \\
\hline Q31 & Efforts to improve, such as eating habits for the lifestyle-related disease prevention & $<---$ Health and medical services & $0.632^{* * *}$ & $0.576^{* * *}$ & $0.653^{* * *}$ & $0.637^{* * *}$ \\
\hline Q21 & Promotion of agriculture, forestry and fisheries & $<---$ Promotion of agriculture, forestry and fisheries & 0.845 & 0.859 & 0.837 & 0.83 \\
\hline Q16 & Secure and develop the leaders of agriculture and fisheries & $<--$ Promotion of agriculture, forestry and fisheries & $0.653^{* * *}$ & $0.605^{* * *}$ & $0.681^{* * *}$ & $0.688^{* * *}$ \\
\hline Q12 & Locality development of agricultural and livestock products & $<--$ Promotion of agriculture, forestry and fisheries & $0.74 * * *$ & $0.69^{* * *}$ & $0.755^{* * *}$ & $0.778^{* * *}$ \\
\hline Q19 & Efforts of infrastructure development such as paddy fields and agricultural irrigation canals & $<--$ Promotion of agriculture, forestry and fisheries & $0.58^{* * *}$ & $0.63^{* * *}$ & $0.54^{* * *}$ & $0.602 * * *$ \\
\hline Q14 & PR activities of the prefecture production of agriculture, forestry and fishery products & $<--$ Promotion of agriculture, forestry and fisheries & $0.696^{* * *}$ & $0.666^{* * *}$ & $0.691^{* * *}$ & $0.75^{* * *}$ \\
\hline Q11 & Direct sales and processing of agricultural product. Efforts of the new business development. & $<--$ Promotion of agriculture, forestry and fisheries & $0.716^{* * *}$ & $0.703^{* * *}$ & $0.708^{* * *}$ & $0.733^{* * *}$ \\
\hline Q18 & Efforts of dissemination and establishment of new breed and new technology & $<--$ Promotion of agriculture, forestry and fisheries & $0.713^{* * *}$ & $0.716^{* * *}$ & $0.725^{* * *}$ & $0.685^{* * *}$ \\
\hline Q13 & Production and provision system of safe and secure county agricultural products & $<--$ Promotion of agriculture, forestry and fisheries & $0.643^{* * *}$ & $0.619^{* * *}$ & $0.639^{* * *}$ & $0.67^{* * *}$ \\
\hline Q43 & The local community building (people collaborate with each other) & $<---$ Volunteer activities & 0.916 & 0.926 & 0.91 & 0.906 \\
\hline Q39 & The residents particip ate in volunteer activities and NPOs, etc. & $<---$ Volunteer activities & $0.783^{* * *}$ & $0.804^{* * *}$ & $0.778^{* * *}$ & $0.721 * * *$ \\
\hline Q40 & Support to the NPO and volunteer activities, etc. & $<--$ Volunteer activities & $0.82 * * *$ & $0.838^{* * *}$ & $0.814^{* * *}$ & $0.766^{* * *}$ \\
\hline Q42 & Services to local residents by a coopretation of prefecture and municipality & $<---$ Volunteer activities & $0.885^{* * *}$ & $0.902^{* * *}$ & $0.879^{* * *}$ & $0.853^{* * *}$ \\
\hline \multirow[t]{6}{*}{ Q41 } & Deployment of new business by local residents & $<--$ Volunteer activities & $0.777^{* * *}$ & $0.782 * * *$ & $0.754^{* * *}$ & $0.81^{* * *}$ \\
\hline & Life Satisfaction & $<--$ Promotion of agriculture, forestry and fisheries & $0.083^{*}$ & $0.134^{*}$ & 0.013 & 0.094 \\
\hline & Life Satisfaction & $<---$ Employment and child care assistance & $0.082^{* *}$ & $0.147^{* * *}$ & $0.124 * *$ & -0.109 \\
\hline & Life Satisfaction & $<---$ Health and medical services & $0.151^{* * *}$ & $0.12^{* *}$ & $0.142^{* * *}$ & $0.207^{* *}$ \\
\hline & Life Satisfaction & $<--$ Promotion of commerce and industry & 0.025 & 0.007 & 0.041 & 0.088 \\
\hline & Life Satisfaction & $<---$ Volunteer activities & -0.002 & -0.027 & -0.008 & -0.002 \\
\hline
\end{tabular}

***Significant at the 1 percent level. **Significant at the 5 percent level. *Significant at the 10 percent level.

Table 4. Reliability Test

\begin{tabular}{llc}
\hline FIT indices & Recommended level & Research Model \\
\hline CMIN/DF & 5.0 (Wheaton et al [20]) 2.0 (Tabachnick and Fidell & $[19])$. \\
CFI & $>0.90$ (Bentler [2]) & 0.906 \\
IFI & $>0.90$ (Bollen [3]) & 0.906 \\
RMSEA & $<0.08$ (Browne and Cudeck [4]) & 0.05 \\
AIC & Smaller values suggest a good fitting (Akaike [1]) & 6074.312 \\
p-value & $>0.05$ & 0.000 \\
\hline
\end{tabular}




\section{Conclusions}

This paper presents a framework and empirical analysis for the survey data from "2014 Citizens Awareness Survey" conducted by the Akita government, in order to gain a better understanding of relationships among more than 2,000 Akita citizens' life satisfaction and the local government policy related factors, such as "Promotion of commerce and industry," "Employment and child care assistance," "Health and medical services," "Promotion of agriculture, forestry and fisheries," and "Volunteer activities."

The results of the research model using SEM show that there are positive and significant relationships between Life satisfaction and those factors; "Health and medical services," "Promotion of agriculture, forestry and fisheries," and "Employment and child care support," although their coefficients of the standardized estimates are small; 0.151 , 0.083 , and 0.082 , respectively. The relationships between Life satisfaction and "Promotion of commerce and industry" and "Volunteer activities" are not statistically significant at all. However, some groups show differences in their responses for promotion of agriculture, forestry and fisheries, and employment and child care assistance. A group of 20-39 years old has more positive perspective on Promotion of agriculture, forestry and fisheries, while 40-59 years and 60 plus age groups do not. Unfortunately, the government statistics reported that about $30 \%$ of new farmers aged 39 or younger have left farming within a few years, because of lack of prospects for living, where some supports from local government are expected. As for a relationship between Employment and child care assistance and Life Satisfaction, a 60 plus age group seems to lose their interests because of their retirement from jobs and child care.

The results imply that Akita local government's policies in "Health and medical services," "Promotion of agriculture, forestry and fisheries," and "Employment and child care support" are related to their citizens' life satisfaction in some extents, while "Promotion of commerce and industry" and "Volunteer activities" are not. Within the report of "2014 Citizens Awareness Survey," it stated that Akita prefectural government meant to measure status quo of each strategy by conducting yearly "Citizens Awareness Survey." The result of the 2014 survey implies the status quo of the local government' strategies have not fully led to life satisfaction of its citizens yet. The improvement of well-being, i.e., life satisfaction of Akita citizens by the local government policy is expected in near future.

\section{REFERENCES}

[1] Akaike, H. (1974), "A New Look at the Statistical Model Identification," IEE Transactions on Automatic Control, 19 (6), 716-23.
[2] Bentler, P. M. (1990). Comparative fit indexes in structural models, Psychological Bulletin, 238-246.

[3] Bollen, K. A. (1989).A new incremental fit index for general structural equation models, Sociological Methods and Research, 17, 303-316.

[4] Browne, M W. \& Cudeck, R. (1993). Alternative ways of assessing model fit, Sociological Methods and Research. 21, 230-239.

[5] Byrne, B. M. (2010). Structural equation modeling using AMOS. Basic concepts, applications, and programming 2nd Ed," New York: Routledge.

[6] Cabinet Office (2011), Measuring National Well-Being Proposed Well-being Indicators-, December 5.http://www5.cao.go.jp/keizai2/ koufukudo/pdf/koufukudosi an_english.pdf. Retrieved on September 5, 2016.

[7] Akita Prefectural Government, 2014 Citizens Awareness Survey (in Japanese)http://www.pref.akita.lg.jp/www/genre/0 000000000000/1139382217159/index.html, Retrieved on September 4, 2016.

[8] Diener, E. (1984). Subjective well-being. Psychological Bulletin, 95(3), 542-575.

[9] Diener, E. \& Diener, M. (1995). Cross-cultural correlates of life satisfaction and self-esteem. Journal of Personality and Social Psychology, 68(4), 653-663.

[10] Diener, E., Suh, E. M., Lucas, R. E., \& Smith, H. L. (1999). Subjective well-being: Three decades of progress. Psychological Bulletin, 125(2), 276-302.

[11] Inglehart, R. (2004). Subjective well-being rankings of 82 societies (based on combined Happiness and Life Satisfaction scores). Retrieved from http://margaux.grandvinum.se/SebTe st/wvs/SebTest/wvs/articles/folder_published/publication_48 8/files/5 wellbeingrankings.doc. Main Link:

http://www.worldvalues survey.org/ Retrieved on September $5,2016$.

[12] Ministry of Agriculture, Forestry and Fisheries (MAFF) (2013). Investigation of agricultural structural dynamics (in Japanese). http://www.maff.go.jp/j/tokei/kouhyou/noukou/. Retrieved on March 8, 2017.

[13] Ministry of Agriculture, Forestry and Fisheries (MAFF) (2015). Agriculture and forestry census (in Japanese). http://www.maff.go.jp/j/tokei/census/afc/2015/top.html. Retrieved on March 8, 2017.

[14] Japan for Sustainability (2013). Creating well-being indicators of Japan, by Japan, for Japan, JFS Newsletter, No. 126.

[15] The Japan Times/Kyodo News (2010). Number of children in Japan falls to record low for 29th year in row. The Japan Times. May 4, 2010. Retrieved September 9, 2016.

[16] Morrison, M., Tay, L., Diener, E. (2011). Subjective well-being and national satisfaction: Findings from a worldwide survey. Psychological Science, 22, 166-171.

[17] Standish, M. \& Witters, D. (2014). Country well-being varies greatly worldwide. Gallup. September 16. http://www.gallup.com/ poll/175694/country-varies-greatlyworldwide.\%20aspx. Retrieved on September 7, 2016. 
[18] Statistical Bureau (2014). Current population estimates as of October 1, 2014. Ministry of Internal Affairs and Communications.

[19] Tabachnick, B. G. and Fidell, L. S. (2007), Using Multivariate
Statistics (5th ed.). New York: Allyn and Bacon.

[20] Wheaton, B., Muthen, B., Alwin, D., F., and Summers, G. (1977), "Assessing Reliability and Stability in Panel Models," Sociological Methodology, 8 (1), 84-136. 